\title{
Reforming state-market relations in rural China ${ }^{1}$
}

\section{Albert Park* and Scott Rozelle**}

*Department of Economics

University of Michigan

Ann Arbor

MI 48109-1220, USA

Tel: (1) 7347642363

E-mail: alpark@umich.edu
**Department of Agricultural and Resource Economics University of California

Davis, CA 95616, USA

Tel: (1) 5307529897

\section{Abstract}

Because of the political importance of stable and affordable food prices, governments in transitional economies in Europe and Asia frequently struggle to balance the desire to maintain state controls in the rural sector with the goal of promoting market development and privatizing or commercializing state agencies involved in rural trade or finance. This paper examines institutional change in China's rural state agencies during the reform period, focusing on the conflict between managerial incentives to maximize profits, on the one hand, and implement policy, on the other. We explain the reasons for changing contractual incentives and authority arrangements over time, assess the effects of new institutional forms on economic performance and policy implementation, and consider reform options.

JEL classification: L33, O53, P20, P31, Q13, Q18.

Keywords: institutions, transition, agriculture, China.

\section{Introduction}

In shifting from state monopolization of the production and distribution of most goods and services in the economy to market-based allocation systems, governments in transitional economies frequently maintain state controls in sectors that affect outcomes of political importance. The rural sector, in particular, is often subject to state intervention because of the high priority given to maintaining stable and affordable prices of staple foods. To that end, state agencies and banks are enlisted to procure and sell agricultural commodities, provide inputs and credit to farmers, and implement price controls or erect market barriers when necessary. These policies, however, are at odds with efforts to promote market development, increase the efficiency of resource allocation in the rural sector, and privatize or commercialize state agencies involved in rural trade or finance. 
This tension manifests itself in transitional economies in Eastern Europe, the Newly Independent States, and Asia. It frequently leads to unexpected or undesired outcomes. For example, in Russia, many local governments ignored the national policy to liberalize grain markets in 1992, maintaining price controls and preventing exports of agricultural goods (Berkowitc, DeJong, and Husted, 1996). In China, the opposite occurred. After liberalization of grain markets in 1993, many local state grain bureaux ignored national efforts to re-implement pricing and other controls in 1994 following rapid grain price inflation. Such different outcomes can be understood only through careful analysis of how institutional incentives facing local government leaders and agency managers evolve over time.

This paper examines the case of China and, in so doing, attempts to provide insights into the process of institutional change. As in other transitional economies, economic reforms have transformed China's rural economy and the roles played by government institutions. In the pre-reform era, the state directed rural collectives to increase grain production while keeping grain prices artificially low to extract surplus for industrial development. The distribution of key agricultural products, agricultural inputs, and rural credit was monopolized by the Grain Bureau (liangshiju), the Supply and Marketing Cooperative (SMC, or gongshao hezuoshe), and the Agricultural Bank of China (ABC, or nongye yinhang). ${ }^{2}$ During the reform period (post-1978), the government's objectives changed. With new goals of improving the efficiency of resource allocation and reducing public fiscal burdens, the government introduced commercialization reforms that provided incentives and new control rights to encourage agency managers to pursue profits in the marketplace. Instead of opposing growing markets, state agencies became increasingly part of them.

Similar reforms were occurring in China's state-owned enterprises (SOEs) with the introduction of the dual-track pricing system and enterprise responsibility system (Naughton, 1995). However, in addition to providing employment, housing, health care, and pensions for state employees (just like SOEs), rural state agencies were responsible for directly administering grain policies, a more difficult task to monitor. The Grain Bureau was still expected to procure grain on behalf of the government and to implement price stabilization policies (sell grain at ceiling prices to urban residents, execute buffer stock operations), the SMC was expected to deliver planned fertilizer allocations and sell fertilizer and other inputs at low prices to support agricultural production, and the ABC was expected to provide loans for state grain procurement, input supply, and poverty alleviation. ${ }^{3}$ Despite reforms, the government strove to maintain a dualist system in which artificially low farm prices kept real state wages high, supporting the slow-to-reform state enterprise sector (Putterman, 1992).

Conflicts between managerial incentives to maximize profits on the one hand, and implement policy on the other, led to widespread evasion of policy directives and caused confusion about the appropriate contractual incentives and division of authority between local governments and managers of state agencies. Policy responsibilities were not stable over time, because the priority placed on different government goals depended on the current state of the rural economy and the availability of government fiscal resources. Also, the rural economy itself evolved over time, most notably in the expansion and deepening of markets, which affected the desire and ability of state agencies to make profits and influence marketing activity in rural areas. With so many factors to consider, the government struggled to find workable institutional arrangements for rural state agencies. To its credit, the government did not hesitate to make bold changes to improve performance. However, by the late-1990s significant problems remained, and new solutions continued to be debated. The success of institutional reform of rural state agencies has important welfare implications for both rural and urban residents. ${ }^{4}$

The story of institutional change in China's rural state agencies provides a compelling 
case study of the complex challenges of designing appropriate institutions in changing environments common in transitional economies. Recent theory in contracts and organizations addressing multitask principal-agent problems (Holmstrom and Milgrom, 1991) and delegation of authority within institutions (Aghion and Tirole, 1997) provide useful conceptual frameworks for assessing the reform-period experience of China's Grain Bureau, SMC and ABC. Drawing on these theories, we explain the reasons for changing institutional arrangements, assess the effects of these changes on economic and policy performance, and consider options for overcoming remaining problems.

The paper is organized as follows. Section 2 describes rural state institutions during the socialist period and reviews the changes in government's goals that led to commercialization reforms. Section 3 provides a conceptual framework for assessing institutional changes, presenting relevant theory on multitask agency problems, delegation of authority or control rights, and external versus internal control mechanisms. Section 4 describes the changes in contractual incentives and the division of control rights associated with commercialization reforms, and the government's later retrenchment to earlier policies. Section 5 discusses the moral hazard problems that undermined the policy functions of rural state agencies. Section 6 examines the effect of market development on the government's ability to regulate markets to support contract enforcement. The concluding section considers current challenges facing institutional reform of China's rural state agencies, recommending the separation of policy and profitmaking activities.

\section{Changing government objectives: motives for commercialization}

During the socialist period, the government owned all assets and reserved most control rights. For nearly three decades, the main goal of the state's production and allocation plan for grain, agricultural inputs, and rural credit was to provide a cheap and stable supply of staple grains to urban workers to support rapid industrialization (Putterman, 1992). The state Grain Bureau established a monopoly over grain trade through laws passed in 1952 and 1954 . Fertilizer distribution was monopolized by the SMC. ${ }^{5}$ All procurement and sales of grain and fertilizer occurred at state-set prices, with access to fertilizer often tied to grain procurement. The $A B C$ supported state plans by providing loans at state-set interest rates to support agricultural production by rural collectives and procurement by the grain system.

Managers under this system received a fixed salary and benefits such as housing and health insurance. Criteria for performance evaluation in state agencies did not include profits and losses, since the manager could not easily influence profits when all transactions and prices were plan-based. Rather, managers were evaluated on how well they provided accurate and timely information to planners, met planning objectives, executed state policies, and conducted political work.

What was the genesis of the move to commercialize rural state agencies during the reform period? Institutional change often results from changes in the objectives of the actors (government or manager) or the economic environment (i.e., technology, regulation, markets) (North, 1990). By the mid-1980s and especially in the early 1990s, four key changes motivated the commercialization of rural state agencies.

The first was the government's commitment to shift from planning to a socialist market economy in order to improve the efficiency of resource allocation and spur growth (Naughton, 1995). The dual-track system in both agriculture and industry 
gradually shifted a larger share of economic activity into the market arena. The government felt that this would improve productivity and direct resources to their most valued use.

A more proximate cause for reform was the fiscal crisis encountered by local governments throughout China. Market competition and price reforms eroded the artificial profits of state enterprises that had long financed public expenditures, and governments at all levels struggled to mobilize fiscal revenues (Wong et al., 1995). By the early 1990s, the problem had intensified, especially in poor areas where many counties had trouble even meeting wage obligations to public officials (Park et al., 1996). Relieving budgetary pressure assumed much higher priority for local governments, making commercialization an attractive option. By improving profit incentives, the government could elicit better financial performance from state agencies. Increasing managerial autonomy also could be used to justify reductions in state support of commercial state agencies. Interviews with grain bureau officials in different provinces suggest that reform occurred more quickly in poor regions with few budgetary resources and which were unimportant sources of national grain supply. ${ }^{6}$

Pressures on the fiscal and financial systems also encouraged reforms that would reduce direct fiscal subsidies. In the early $1980 \mathrm{~s}$, grain subsidies accounted for over onefourth of total budgetary revenues (Rozelle et al., forthcoming). The government was unable to finance procurement of the record harvest of 1984 at government-set, abovequota prices, leading directly to the contracting system and initial market participation by state traders (Sicular, 1988). Similarly, the inability of state banks to finance burgeoning inventories of fertilizer in 1985 led the government to liberalize fertilizer markets, allowing SMCs, for the first time, to sell fertilizer wherever they could at whatever price they could get, and to allow farmers and others to freely enter into market trade (Stone, 1989). Poor financial performance by banks also contributed to the decision to push forward with reforms designed to commercialize China's specialized banks.

A third driving force for commercialization was market development. In all three sectors, state agencies faced increasingly stiff competition in growing markets. Grain bureaux competed with other grain bureaux and private traders. SMCs competed with agricultural extension stations, other state units, and private traders. The $\mathrm{ABC}$ competed with other specialized banks, Rural Credit Co-operatives, and, in some areas, with private credit co-operatives or other quasi-formal and informal financial institutions. ${ }^{7}$ In each case, competition made profit-earning more difficult, providing greater pressure on the government to let state agencies compete in markets on an even footing or face significant financial losses.

Finally, an additional correlate of reform was the urgency of rural policy objectives. Reforms in all three sectors moved forward most rapidly in the mid-1980s and early 1990s when grain and fertilizer prices were stable and overall inflation low (Rozelle, 1996). Despite new pressures accompanying reform, the government did not abandon its goal of producing abundant, low-priced grain, which we refer to as the 'traditional' policy goal.

\section{Theory}

The managers of state commercial agencies can be viewed as employees (or agents) of local government officials (the owner, or principal). ${ }^{8}$ Several aspects of institutional design affect the relationship between principal and agent. First, the government sets contractual incentives for the manager, anticipating how these incentives will affect the 
manager's effort in completing different tasks that affect the pay-offs to the principal. Here, the principal's objective is not solely profit maximization. The government's new efficiency and budgetary goals are consistent with profit maximization, but its traditional policy goal is not. Thus, in the reform period the government has dual objectives-profit maximization and the traditional policy goal; in the socialist period, only the latter.

When an agent has multiple tasks, Holmstrom and Milgrom (1991) show that the desirability of providing agents with incentives for one activity decreases with the difficulty of measuring performance in other activities that compete for the agent's time and attention, and which are important to the principal. ${ }^{9}$ Task-specific incentives can still work well if the hard-to-measure tasks are complementary to easily measured tasks. But when they are not, which is typical when two activities compete for the agent's time, weak incentives may be appropriate even when some tasks are easily measured. Optimal job design is to make each task the responsibility of different agents if possible, or group easily measured tasks and hard-to-measure tasks into separate jobs. Below, we argue that these ideas help explain the policy failure associated with strong profit incentives created by commercialization reforms, and that they point to the appropriate and likely direction of future reform.

Second, the government keeps or delegates control rights. Contracts are unlikely to specify the responsibilities and actions of each party in all contingencies, or for all projects. ${ }^{10}$ With incomplete contracts, the contract may explicitly or implicitly allocate formal authority (or control rights) over different decisions to one of the parties. But even when the principal maintains formal authority (final approval rights) it may delegate real authority (or effective control) to the agent (Aghion and Tirole, 1997). Aghion and Tirole (1997) find that the benefit of delegating formal authority is the increased initiative of agents, but the cost is loss of control over projects. Loss of control can be particularly costly if the goals of agent and principal are not congruent. When the principal maintains formal authority, there are several relevant results: (1) the real authority of agents should increase with better performance measurement; (2) if the agent does not trust the principal (gains little from the principal's preferred project) there will be little communication; and (3) the principal is more likely to rubberstamp decisions the more urgent the decision.

The commercialization reforms implicitly delegated formal authority over many market trade decisions to managers, who did not have to seek approval from upper levels for their decisions. This led to greater initiative by managers, who sought out new profitable (even unconventional) trade opportunities. Managers also agreed to continue administering government policies. For these decisions the government maintained formal authority even though much real authority devolved to managers. When unanticipated contingencies led to policy retrenchment, the government tried to re-assert its authority, making demands that many managers felt were unreasonable. Unfortunately, limited administrative capacity and the urgency of new policy measures forced leaders to rely on managers even though performance was difficult to measure. Agents lacked trust in managers, because their interests were not aligned, limiting communication. We argue that the government underestimated the cost of lost control caused by goal incongruence created by new profit incentives.

Third, unlike a firm, the government has the power to influence the economic environment in which the agent operates, or what Laffont and Tirole (1991) refer to as external (versus internal) control. The government is not only the manager's employer, but also the regulating agent and tax collector. Local governments in China can influence market conditions directly by restricting competition by law, by imposing licensing and other requirements on private agents, or by imposing market barriers to prevent goods or resources from flowing in to or out of local regions (Wedeman, 1993). Larger markets are harder and more costly to control, which affects the ability to enforce external 
controls and so affects the incentives of traders. For example, if inter-regional trade can be restricted when agents are expected to perform policy tasks, the pay-offs of policy evasion may fall, making the government more willing to provide profit incentives to agents.

\section{Institutional reform}

Commercialization reforms increased contractual incentives to earn profits and gave greater authority to managers in exchange for greater fiscal self-reliance. Later, however, the government tried to re-centralize authority and restrict managerial control. In this section, we describe these institutional changes for the three rural state agencies, setting the stage for Section 5 , in which we evaluate the performance of reformed institutions and explain reasons for policy failure.

\subsection{Incentives}

During the reform period, institutional changes in all three rural state agencies awarded a greater and more explicitly defined share of profits from market trade to managers. In return, agencies were expected to become fiscally self-reliant, the typical pattern of China's fiscal decentralization. These changes provided concrete incentives for agents to pursue profit maximization, but not to meet policy objectives.

When grain managers first began engaging in market trade in the mid-1980s, the employment contract did not change significantly. Sharing rules for profits were not clearly enunciated. Profits from negotiated trade might be used to cover losses from policy operations. Even with a predatory government and ill-defined rights to profit retention, some of the additional resources were typically retained by grain managers to award as bonuses, improve housing and other facilities, pay for business entertainment expenses, or invest in new infrastructure or other ventures. ${ }^{11}$

During the early 1990s, with budget pressures intensifying and with the phase-out of grain rationing and procurement, the income claims of local government and managers of rural grain stations and urban grain outlets were set out more explicitly in profit-sharing or fixed payment contracts. In most regions, the pay of both managers and workers became much more dependent on profits. The changes occurring in Guizhou were typical. Beginning in 1994, grain station managers and employees were paid only 70 per cent of regular government wages (versus 100 per cent before). In 1995, this percentage fell to 50 per cent. Grain stations were permitted to retain 50 per cent of all profits for bonuses and other services or benefits for managers and workers. The other 50 per cent went to cover losses from policy operations. In a county in Shaanxi Province, the managers of all 16 grain stations had signed profit-sharing contracts, and most workers were paid solely on a commission basis. For the first time, grain bureau agents began to go directly to villages, competing with private traders, to increase negotiated procurement. ${ }^{12}$ Similar institutional changes were occurring for urban retail grain outlets (Rozelle et al, forthcoming).

As a result of these new opportunities to benefit from trade, the volume of non-quota, or market-based, state procurement of grain increased rapidly. By 1992, the relative shares of market-based and planned procurement had reached 55 and 45 per cent, compared to 25 and 75 per cent in 1985 (Sicular, 1995). After market liberalization in 1993, there was a noticeable increase in the shares of non-quota state procurement and especially free market purchases in the total grain trade; the share of quota procurement at fixed prices fell (see Figure 1). 
At the same time that grain markets were being liberalized in 1992-93, the government relaxed restrictions on fertilizer trade. Many township SMCs began contracting out fertilizer trade to individuals on a fixed-rent basis, making managers sole residual claimants. ${ }^{13}$ The introduction of such contracting was not official policy, but increased steadily. Just as for the state grain trade, the new contracts clarified the property claims to profits earned by managers. Similar contracts had also begun to emerge in the late 1980s after the first liberalization of the fertilizer trade (Ye, 1991). ${ }^{14}$

Managers of $A B C s$ increased their share of profits as well. Profit retention by $A B C s$ first began in 1983 in the form of three-year contracts. Since 1988, the ABC, unlike other specialized banks, has operated under a contract responsibility system. Income tax and other targets are agreed upon with the finance bureau, and residual profits are retained by the $\mathrm{ABC} .{ }^{15}$ Similar contracts are struck with county and some township branches. Profits can be passed on to workers as bonuses. The bonus share of salaries of managers and workers at the $\mathrm{ABC}$ has risen consistently throughout the reform period, growing from 9 per cent in 1980 to 14 per cent in 1985 and 24 per cent in 1992 (State Statistical Bureau, 1994). In addition to these financial incentives, Zhu Rongii's financial reforms in 1994 put enormous administrative pressure on bank managers to improve profitability, emboldening them to resist interference from local government leaders in lending decisions. These reforms improved the incentives for $\mathrm{ABC}$ managers to maximize commercial profits.

Figure 1. Grain market activity by types of traders in China, 1978-95

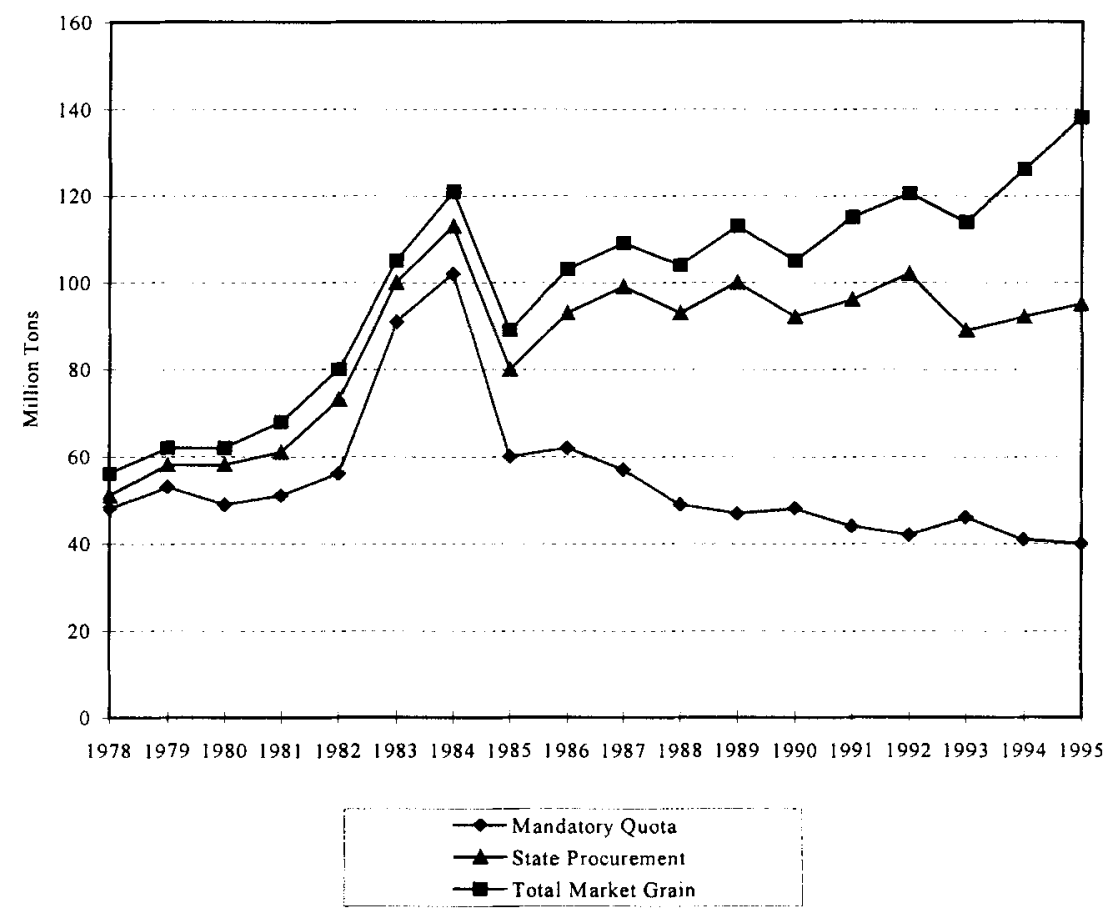

\subsection{Authority and control rights}

Along with greater profit incentives came expanded control rights which allowed managers to engage in trade of different goods and to choose their trading partners. For 
market trade, there was a devolution of formal authority to managers, who did not require government approval for most decisions. Although the assets of individual grain stations were owned by the state, in practice the manager of the station exercised considerable residual control over these assets, mainly because of the difficulty county bureaucrats had in monitoring their use. ${ }^{16}$

State grain managers were first allowed to engage in market trade in 1985, when they began purchasing and selling grain at negotiated prices (vijia) typically well-above the official procurement price (pingjia) (Sicular, 1995). Transactions at these prices were voluntary, and grain stations were not restricted in selecting trade partners. Many grain stations procured some of their negotiated grain from local private traders. Negotiated prices soon began to move closely with market prices. ${ }^{17}$ Grain managers who had contracted out state assets were also given more latitude to engage in trade of goods other than grain (e.g., inputs, cash crops) if they could do so profitably. Grain trading companies also diversified to other commercial ventures such as restaurants and hotels. At the same time, and especially by the early 1990s, the government sharply reduced direct state interventions in the grain economy, reducing policy-related restrictions on control rights. ${ }^{18}$

Managers of SMCs were also allowed to set market-based prices for fertilizer for the first time in 1985 (Stone, 1989). At the same time, farmers and private traders were permitted to engage in fertilizer trade. Unlike earlier periods, sourcing of fertilizer was not restricted. Traders could go across county and provincial boundaries to procure fertilizer. Grain supply shortages and grain price increases - in part attributable to erratic access to fertilizer - made these freedoms short-lived. The government recentralized distribution channels and reimplemented price controls beginning in 1987. A similar liberalization occurred in the early 1990s, once again to be reversed in 1994.

Reforms to commercialize state specialized banks began as early as 1979 , with reforms deepening in the late $1980 \mathrm{~s}$. ${ }^{19}$ The scope of $\mathrm{ABC}$ lending broadened considerably, beginning in 1985 when $\mathrm{ABCs}$ began to lend to industrial township enterprises (World Bank, 1990). By the early 1990s, the state was encouraging all four specialized banks to compete directly in making loans to all sectors of the economy rather than specializing in specific sectors. New control rights also increased the ability of banks to generate loanable funds. Beginning in 1980, lending plans were linked to the amount of local deposits (Cheng, 1996). ${ }^{20}$ The introduction of an interbank market for loans increased the ability of managers to move funds across regions (Xia, 1995). Interest rates, however, remained highly regulated, especially for deposits, though slight adjustments to loan interest rates by local banks were permitted.

\subsection{Retrenchment}

The commercialization reforms of the early 1990s took place during a period of plentiful grain and low price inflation, which made the government optimistic that the policy roles of state agencies would remain limited and could be gradually reduced over time. However, in all three sectors, the government soon pursued retrenchment policies in reaction to emerging economic problems, imposing restrictions on newly granted control rights of managers. Policy retrenchments in all three cases were associated with episodes of high grain, fertilizer, or overall price inflation - for grain in 1988 and 1994, for fertilizer in 1987 and 1994, and for credit in 1989 and 1994. Here, we describe the later episodes, times in which conflicts among parties were greatest because of commercialization reforms.

In retrospect, the government viewed the commercialization reforms as a contingent delegation of authority, dependent upon continued stability in national grain, fertilizer, and credit markets. In times of crisis, the government reserved the right to exercise control rights, ${ }^{21}$ and managers and workers were expected to implement official policies 
obediently. But many managers felt that implicitly they had been granted formal authority over market trade decisions in exchange for agreeing to greater fiscal self-reliance. If the contract was contingent, they disagreed over when contingencies warranted a change in the agreed upon division of control rights, whether the actions requested of them were reasonable, or in what way contract terms should be adjusted (e.g., the level of compensation for policy-related activity).

Few people anticipated the rapid grain price inflation in China during 1993 and 1994. From late 1993 to mid-1995, real rice prices rose 75 per cent and wheat and maize prices rose by about 60 per cent (Rozelle et al., forthcoming). ${ }^{22}$ An unprepared Chinese government tried to combat the inflation with traditional policy tools. Price controls and different forms of rationing were imposed in urban areas, procurement obligations that had been reduced or eliminated were reinstated, and a number of local governments prohibited grain outflows from their regions. The government ordered grain stations to release government grain stocks at ceiling prices to help stabilize the market.

Concerns that grain market liberalization had led to a sharply negative supply response by farmers also led the government to pursue measures to bring down fertilizer prices to support agricultural production. ${ }^{23}$ The State Council issued a circular in 1994 on reforming the fertilizer distribution system and another in late 1995 on deepening reform of SMCs. According to the new regulations, all fertilizer prices were to be set by government price bureaux, with a strictly regulated retail mark-up. ${ }^{24}$ The only agencies permitted to sell fertilizer locally were the SMCs, agricultural research and extension stations, and factories. ${ }^{25}$ Contracting of fertilizer trade to individuals and trade by any other agencies (including private traders) was prohibited. In short, the government attempted to control the market by restricting marketing channels and controlling the price. In 1995, the government also reinstated the linkage of subsidized fertilizer to grain procurement (sanguagou), which had been eliminated in 1993.

In times of inflation, the state also relied on administrative measures enforced by the banking system to bring prices under control (Tam, 1995). The government switched from indicative guidance planning to strictly enforced administrative plans for credit allocation (Brandt and Zhu, 1997). In the 1994 macroeconomic retrenchment, this meant that $\mathrm{ABC}$ managers faced scarcer capital and restrictions on lending to new projects. With procurement quotas returning to earlier levels in many areas, the financing demands on ABCs increased.

\section{Moral hazard and the evasion of policy directives}

New profit incentives created by commercialization reforms and expectations of managers to implement retrenchment policies came into direct conflict. The state failed to anticipate the difficulties in local policy implementation that would be caused by the new commercial role of state agencies. Government leaders did not understand why old methods of control no longer seemed to work.

\subsection{Grain bureaux}

Grain managers subverted many of the new policy mandates of 1994. Urban managers sold only extremely low quality grain at the official price cap, reduced the hours such grain was made available, and eliminated services accompanying the sales. ${ }^{26}$ These responses attempted to minimize the effect of lost control rights embodied in new policies by creatively utilizing remaining control rights. ${ }^{27}$ Grain managers were reluctant to allocate employees' time for procurement activities for which profit margins were 
inferior to negotiated trade, especially if it alienated farmers with whom they hoped to engage in market trade. They were also reluctant to release grain stocks at prices that were not profitable or pass up profitable trade opportunities restricted by regulations or blockades. For example, a county grain trading company in Jiangxi illegally sold government grain stocks to Guangdong at a high price and had nothing left to sell when the government ordered it to sell stocks to stabilize local prices. ${ }^{28}$ Given the long history of failed subsidy payments, managers remained sceptical that government subsidies would be forthcoming for their policy activities. In some cases, official subsidies decided by planners with inadequate adjustments for local regions were not enough to cover actual costs anyway. At the same time, many grain bureaux took advantage of banks by claiming operating losses from market trade as policy losses deserving of rescue loans (Cheng, 1997).

Thus, despite a concerted effort to control the grain sector, grain prices continued to rise, and price ceilings in urban areas were raised several times. Many viewed the stabilization measures as a failure. Leaders in almost all regions complained of the breakdown in policy implementation at lower levels (Ding, 1995).

\subsection{Supply and marketing co-operative}

Similarly, the new policies to control fertilizer prices, beginning in 1994, were a failure (Wu, X., 1994; Zhang, 1994). Actual prices paid by farmers were well above the government guidance prices and, in most areas, private trade in fertilizer continued to flourish. ${ }^{29}$ For instance, although the state had set a base factory price for urea of 1,000 yuan per ton (with a 15 per cent adjustment limit), and a national retail sales price cap of 1,400 yuan, at the beginning of 1994 the average retail price in China was 1,600 yuan and by August, 1995 it had reached 2,010 yuan, nearly 50 per cent higher than a year earlier (Wu, X., 1994). Fertilizer prices continued upward in 1995 and 1996, and many fertilizer producers and marketing agents ignored regulations to sell their products through state channels at below-market prices. A survey of 184 villages in six provinces by the authors provides evidence of the growing role of private traders in fertilizer sales to farmers (see Figure 2). In all six provinces, the average fertilizer market share of private traders increased significantly from 1988 to 1995 , in two provinces (Shaanxi and Shandong) exceeding 20 per cent of sales. ${ }^{30}$

Problems in controlling fertilizer markets were reminiscent of the late $1980 \mathrm{~s}$ following the initial period of liberalization (Stone, 1989). During that period, moral hazard manifested itself in several ways: SMCs did not deliver entitled planned fertilizer allocations (subsidized), often diverting it to friends and relatives; SMC officials took bribes or colluded with private traders to capture rents from high free market prices; and deliveries of fake or adulterated fertilizer increased (Lyons, 1992). ${ }^{31}$

To achieve a more reasonable price and evade the official mark-up restrictions, SMC managers frequently inflated transport costs (which could be legally added to the retail price). The handling costs by local SMCs were about 20 per cent of the wholesale price, much greater than the 10 per cent allowable mark-up. Because it is easier to enforce price controls at the factory gate than at the farm gate, trade intermediaries captured most of the rent implicit in the gap between plan and market prices, providing an even greater incentive for traders to evade new regulations. 
Figure 2. Market share of private fertilizer traders, 1988 and 1995

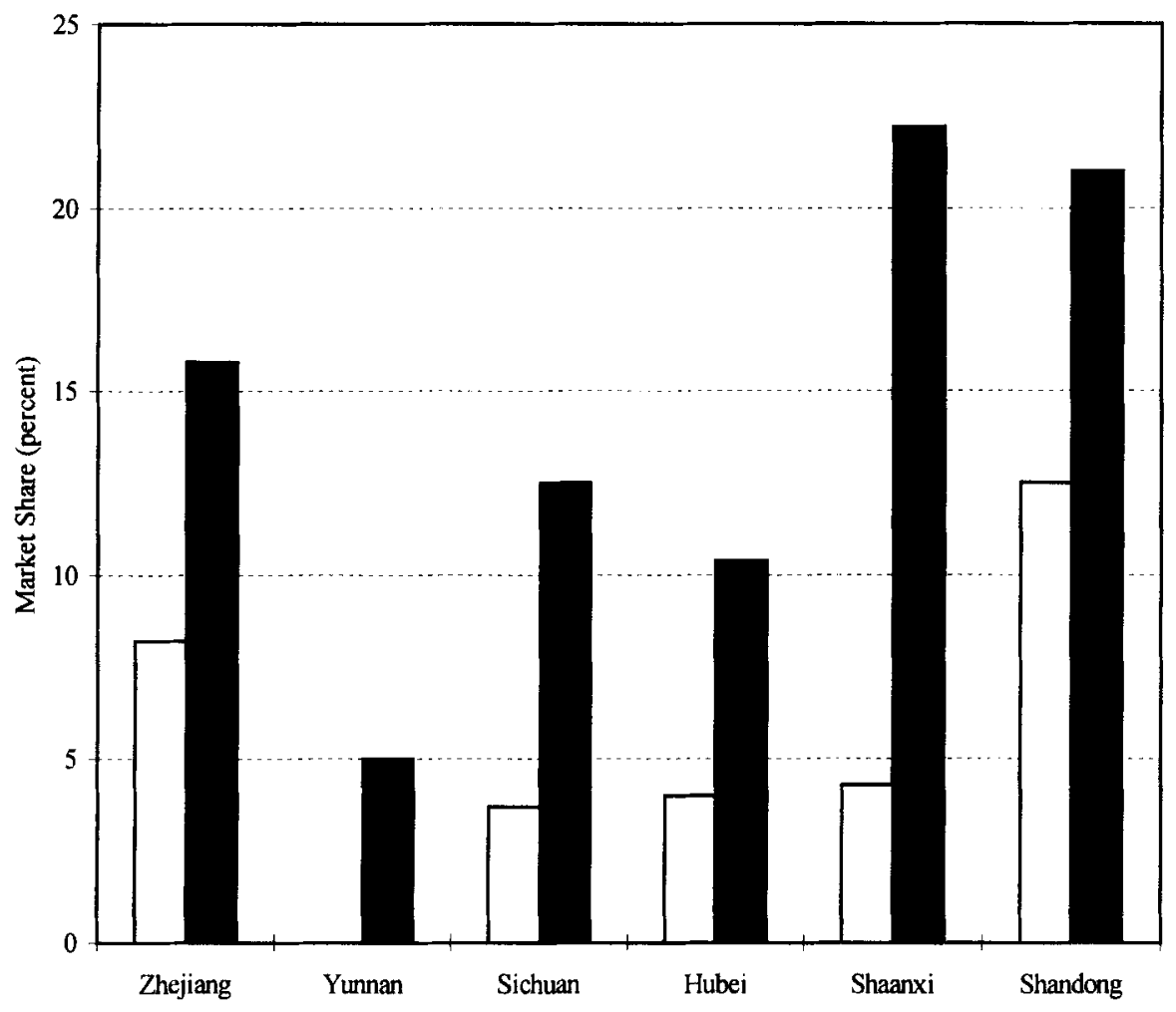

\subsection{Agricultural Bank of China}

As in other sectors, profit incentives undermined the willingness of bank managers to be instruments of policy when doing so was costly. In 1988, the year of the new contract system, the problem of grain bureaux issuing IOUs (or baitiao) to farmers for procured grain became widespread. About 10 per cent of funds for grain purchases and 21 to 27 per cent of funds during the autumn purchase season were paid in the form of IOUs. In parts of central and western China, the percentage reached as high as 50 per cent (Cheng, 1997). IOUs were the result of Agricultural Banks failing to provide subsidized loans to the grain bureaux. Instead, available funds went to rural enterprises and other high return projects. Brandt and Zhu (1997) argue that diversion of funds in state banks to the nonstate sector was a main cause of inflationary cycles in China. In most cases, loans to the grain bureaux were eventually made by local $\mathrm{ABCs}$, but only when financed by lowinterest loans from the People's Bank of China (PBC). IOUs to farmers thus were used by $\mathrm{ABCs}$ to signal the need for additional funds. Despite strong administrative efforts to eliminate IOUs, the problem emerged again in some areas in 1993 (Cheng, 1997). Evasion of policy duties also affected subsidized poverty alleviation loans. ${ }^{32}$ 
The soft budget constraint for procurement loans and the difficulty in monitoring loan use led to poor repayment performance on procurement loans. Policy loans to the Grain Bureaux could be easily diverted to market-oriented use or to housing construction or other benefits for managers and workers. Grain bureaux could claim large policy losses (for example, declare losses from negotiated trade as policy losses or exaggerate costs), and local bankers could not easily distinguish between which expenditures and costs were policy-versus market-related. Local governments, too, took advantage of the soft budget constraint by refusing to pay required subsidies to cover the costs of price subsidies and official grain storage, correctly anticipating that the $\mathrm{PBC}$ and $\mathrm{ABC}$ would bail out the Grain Bureaux. The problem continued after procurement loans were shifted to the newly created Agricultural Development Bank (ADB) at the end of 1994. By 1997, the total grain debt included 130 billion yuan in defaulted loans. In 1996, loans from the ADB, almost all for procurement, accounted for 13 per cent of all loans from formal financial institutions in China. PBC financing of procurement loans was an admission that ABCs would only make policy loans if doing so was profitable. ABCs benefited from this and even exploited it. ${ }^{33}$ The ABC/ADB discounted losses from policy loans because they were confident that the government would ultimately bear the financial burden.

\subsection{Discussion}

Why did the new profit incentives and control rights to promote commercialization of rural state agencies lead to such policy failure? One important reason was the difficulty in measuring performance in fulfilling policy tasks. As pointed out by Holmstrom and Milgrom (1991), poor performance measurement leads agents to divert effort away from poorly measured activities to easily measured activities with high-powered incentives. For all three agencies, multi-tasking itself made measurement difficult, because it was impossible to distinguish between policy and commercial transactions when the staff and facilities were the same for both activities. For example, grain procured at quota and negotiated prices were perfectly fungible; it was difficult to verify at what price grain had been sold or the costs attributable to policy versus market activities. The administrative ability to monitor branch managers within a county was limited and compounded by the fact that local leaders had an incentive to collude with managers if the policy benefits were not highly localized or did not outweigh the value of saved budgetary outlays. Unlike SOEs, where workers have an incentive to monitor the managers' fulfilment of state obligations to them, for grain policy tasks, no-one within the state agencies had an incentive to report non-fulfilment. A second reason for performance problems was that the two tasks of pursuing profits and implementing policy were not only not complementary, but clashed head on, exacerbating the incentive problem. Given the incentives put into place, the government also made a mistake in delegating so much authority to managers when the goals of principal and agent were so incongruent, performance measurement so problematic, and the cost of lost control so high. The mistakes can be attributable to a panic response to emerging problems, a false confidence in administrative enforcement ability or the obedience of managers, and a lack of confidence in using new, market-based mechanisms.

\section{Market development and external control}

Part of the concern about whether specialized policy agencies could influence market outcomes stems from the expansion and deepening of nural markets. Market growth has 
implications for the government's ability to realize external controls on firm behaviour, the costs of such actions, and the financial viability of rural state agencies given increased competition. Even when trade flows cannot be stopped fully, governmenterected market barriers can increase the costs of trading, and reduce the incentive to evade policy duties (or the incongruence between goals of principal and agent). A manager may be less likely to expend effort to contravene policy by selling grain or fertilizer to outside markets if the expected return to doing so has fallen.

But the effectiveness of such an incentive scheme depends on the ability of governments to regulate market trade, which, in turn, depends on the number of marketing channels, the dispersion of trade, monitoring costs, and administrative capacity. In China, the reform period has seen rapid growth of markets for grain, fertilizer, and credit, ${ }^{34}$ and each of these markets had characteristics which caused difficulties in imposing market trade barriers. Thus, market development reduced the ability of governments to employ external controls to encourage contract compliance by managers. These difficulties exacerbated the problems caused by strong profit incentives.

To support price controls in 1988 and 1994, many local governments attempted to restrict grain outflows to other regions. However, even though the ability to focus enforcement efforts on provincial or prefectural borders should facilitate market control, by the early 1990s the channels through which grain could flow, both between regions and indirectly through common trading partners, had increased so substantially that efforts to control market flows usually failed. ${ }^{35}$ Grain markets remained relatively integrated even after policy retrenchment in 1994 (Rozelle et al., 1998). Russia, too, has seen increased food market integration despite local price controls (Berkowitc, DeJong, and Husted, 1996). The failure of price controls for grain is common to other developing countries (Bates, cited in Eggertsson, 1990).

Although fertilizer market expansion lagged behind grain markets and was subject to tighter controls, the greater geographic dispersion of the market made fertilizer trade particularly difficult to regulate. Purchasers of fertilizer are farmers scattered throughout the countryside, while purchasers of grain are urban residents concentrated in cities. Fertilizer factories exist in every province, and most trade flows are within a province rather than between provinces. The government thus cannot focus its enforcement efforts on inter-provincial boundaries as for grain, but instead must mobilize enforcement effort in every county and township. Even in the late 1980s, when fertilizer trade had just been liberalized, it was difficult for the government to regain control of market activity.

Credit markets have been subject to considerable regulation, and only recently have non-banking institutions been able to serve as financial intermediaries. As noted earlier, village and township-based credit organizations have also emerged in some areas. Because flows of financial capital are invisible - not being a physical good, there are no visible transport routes or marketplaces-external controls are not viable, and regulation must focus on internal controls at the firm level. Even then, it can be difficult to monitor where bank funds are being lent, since accounts are easily hidden or mis-reported. Highpowered profit incentives and growing opportunities for high return investments given more integrated and diversified financial markets (including stocks and bonds) undoubtedly creates greater incentives for policy loans to be diverted.

\section{Reform challenge: separating policy from profits}

One of the main contributions of this study is that it demonstrates that many of the institutional problems facing different state agencies in China can be understood in a 
common framework. Similar issues face any government agency that is being made fiscally independent to reduce the state's budgetary obligations. State-market relations have entered a state of flux as the Chinese government struggles to adapt institutions and contractual arrangements to new environments. The dilemma is a stark one. Intense budgetary pressures make a retreat from profit-based incentives unpalatable if not unworkable. But recent experience has convincingly shown that such incentives, along with market development, severely undermine the ability of governments to implement policies aimed at achieving other social objectives.

Continued confusion over how to resolve this tension was evident in the language of the State Council circular of December, 1995 on the deepening reform of SMCs:

\begin{abstract}
'The management mechanism of the supply and marketing cooperatives must be established with service to co-operative members rather than profits as the main objective. Other economic activity should be commercially managed, achieve higher economic returns, and continually be strengthened on the foundation of service to farmers.'
\end{abstract}

On the one hand, the circular recognized the need for SMCs to be more marketoriented, calling on them to be independent, legal accounting units responsible for losses and willing to adopt different forms of internal responsibility systems to improve incentives. On the other hand, it called for greater vigilance in ensuring compliance with government policies, banning the contracting out of fertilizer trade to individuals, ${ }^{36}$ urging local governments to correct 'improper' institutional reforms and resolve policyinduced losses, and ordering the establishment of new monitoring units at the county level to ensure policy compliance (CCCPSPC, 1995).

Such directives reflect a continuing propensity of leaders to solve policy implementation problems by brute force administrative measures akin to political campaigns rather than through more fundamental institutional reform that recognizes the importance of designing appropriate incentives for agents increasingly involved in a market economy that planners can influence but not control. But Chinese leaders, too, are learning from experience.

One promising idea for institutional reform for all three agencies, and one suggested by theory, is to achieve a clearer institutional separation of policy and profit functions, so that different agents perform different tasks. Beginning on January 1, 1996, the State Council ordered that commercial and policy staff be separated in the grain bureau system by designating persons in each department to be responsible for one job or the other. ${ }^{37}$ In 1998, reform of the grain marketing system was one of the key reforms announced by the new premier, Zhu Rongji. Recognizing that 'the main problems in China's grain marketing system lie in the fact that the state-owned grain companies play a dual role' (China Daily, 1998), the government announced an ambitious plan to clearly separate commercial and policy operations by fully commercializing grain trade while establishing a fully independent government grain buffer stock system to stabilize grain prices. New accounts are to be kept separate from the old accounts to strengthen accountability.

Similarly, the December, 1995 State Council circular (cited above) called for separate accounts to be established for commercial and policy-related trade of SMCs. By mid1996 , local governments were still in the process of complying with the new regulations, and it remained unclear how effectively they would be implemented.

As described earlier, in rural finance, a new institution, the Agricultural Development Bank (ADB), was established in 1994 to take over policy loans, freeing the ABC to become a true commercial bank. ${ }^{38}$ Pay for managers and workers at the ADBs had a 
smaller bonus component than for those at $\mathrm{ABCs}$, while base compensation was higher. ${ }^{39}$ The contracts thus differed in a way consistent with the different managerial authority and objectives of the two institutions.

Continued progress in this direction would make China's rural institutions more closely resemble those in other market economies. For example, Indonesia, before the recent financial crisis, had achieved a remarkable record of rice price stabilization through buffer stock operations administered by state agencies that do not engage in trade for profit. Market trade is dominated by private commercial traders. In India, government employees operate grain ration shops to distribute below-market-priced grain and oil to urban and rural residents, and are not allowed to engage in marketoriented transactions. Similarly, many other countries have both policy and commercial banks that operate independently.

Even when fully relinquished of direct policy duties, commercialized trading companies and banks in China will still be state-owned enterprises with all the incentive problems associated with public ownership, especially welfare obligations to employees and soft budget constraints. Even with independent policy operations, there still may be moral hazard and other problems that prevent effective implementation, as seen in the poor repayment performance and loan diversion of the Agricultural Development Bank. The experience with commercialization to date shows that the built-up human capital and sizeable physical capital of rural state agencies, especially grain bureaux, provides them with advantages in market trade. But the experience of many SOEs also demonstrates that, as market competition intensifies, losses may mount and bankruptcy or quasiprivatization becomes more difficult. These considerations suggest that it might make sense to move quickly with reforms to fully commercialize state trading companies and sell or lease public assets to managers, which will also improve managerial incentives.

Travelling such a road, of course, is not without risks. Full abdication of control rights in fully commercialized firms trading agricultural inputs, outputs, and rural credit would represent a significant reduction in the government's presence in rural markets. The gradual pace of reform has provided time for learning how new institutions will operate, reducing the possibility of instability that is anathema to the Chinese leadership.

\section{Endnotes}

1. This is a substantially revised version of a paper titled 'Commercialization of the State in Rural China', prepared for a conference on 'Property Rights in Transitional Economies: Insights from Research on China' at Hong Kong University of Science and Technology, June 13-15, 1996. Albert Park acknowledges support from a USIS Post-doctoral Fellowship for Collaborative Research in the PRC from the Center for Chinese Studies, University of California at Berkeley. The authors thank Loren Brandt, John Giles, Chuck Gitomer, Jikun Huang, Jean Oi, Suwen Pan, Andrew Walder, Sangui Wang, Guobao Wu, and conference participants in Hong Kong for helpful suggestions.

2. The $\mathrm{ABC}$ was established and dissolved three times during the socialist period before being re-established permanently beginning in 1978 (Xu et al., 1994). When it did not exist, similar functions were performed by the People's Bank. Rural Credit Co-operatives also operated at the village level under the administrative supervision of the Agricultural Bank.

3. In 1994, most policy loans were taken over by the new Agricultural Development Bank. 
4. There are over 400,000 grain stations in China's rural areas, over 700,000 supply and marketing co-operatives (SMCs), and over 60,000 branches of the ABC. Millions of rural households interact regularly with the local branches of these organizations. The agencies are also major public employers. The grain bureau system had over two million employees nationwide in 1992 (two-thirds in urban outlets), the SMCs nearly 5 million by the late 1980 s, and the ABC over 500,000 in 1994, more than any other specialized bank. Sources for grain bureaux are Cheng (1994) for number of grain stations, Rozelle et al., (1996) for number of grain bureau employees, State Statistical Bureau (1989) for data on SMCs, and State Statistical Bureau (1995) for data on the ABC. Rural credit co-operatives (xinyongshe) are also often found at the village or township level, and report to the local $\mathrm{ABC}$.

5. The Agricultural Inputs Company (nongye shengchan ziliao gongsi) of the county SMC arranges for procurement and delivery of goods to the county level. While named co-operatives, SMCs operate as state marketing agents.

6. Reform was also faster in prosperous, grain deficit provinces in southern China, where the opportunity cost of growing grain was high, and higher income levels made grain price increases easier to accommodate.

7. For example, Rural Credit Foundations (nongcun hezuo jijinhui), township-level credit organizations organized by local agricultural officials, have grown to rival the size of local ABCs and state-supported rural credit co-operatives.

8. We focus on officials and agency managers at the county and township levels, where most trade and policy decisions affecting rural areas are implemented.

9. For example, the authors cite concerns that merit pay for teachers based on test scores, their performance in one task, leads teachers to neglect other important duties, such as stimulating creativity and other difficult-to-measure aspects of learning.

10. The principal-agent framework is useful for assessing the rationale for many contract terms, but it makes the strong assumption of complete contracting, or that contracts can be perfectly specified for all contingencies.

11. These benefits can be considered claims to the residual if they are benefits that correlate with performance but are not explicitly contracted. Even with contracts, to the extent that managers can make hidden investments and hide revenues from market trade, they may become residual claimants.

12. Interviews by the authors in Guizhou Province (April 1996) and Shaanxi Province (1994)

13. Interviews with county SMC officials in Guizhou Province (April 1996) and Hebei Province (1995). In general, the outlets that were not contracted out were ones earning losses, since they were not viably self-supporting.

14. Although they are technically collectives, SMCs operate very much like government agencies. They adhere to wage and employment plans set by local governments, their managers are appointed, and they implement government directives. However, unlike grain bureaux, SMCs have never drawn wages from local government budgets. Instead, all wages and bonuses have had to be paid from revenues

15. The $\mathrm{ABC}$ agreed to remit 2.45 billion yuan per year in taxes and profits to the government, above which only 10 per cent of profits were to be remitted (Xu et al., 1994).

16. Milgrom and Roberts (1992) point out that in large organizations it is often difficult to distinguish who has residual control over assets.

17. In the initial years of negotiated trade, some grain bureaux put price bounds on 
negotiated prices set by individual grain stations. The negotiated price also tended to be lower than the market price. In the late 1980s and early $1990 \mathrm{~s}$, many areas imposed above-quota obligations purchased at a state-set negotiated price that varied from the market price. Over time, the gap between negotiated and market prices has fallen.

18. The share of grain production procured at fixed prices fell through the late $1980 \mathrm{~s}$. After several good harvests, the government decided to move ahead with market liberalization policies, phasing out rationing and subsidies for urban grain sales from 1991 to 1993 , raising the procurement price to market price levels in 1993, and eliminating nationally-subsidized relief sales of grain to rural areas (fanshaoliang). These sweeping reforms were implemented with surprisingly little disruption to China's grain markets.

19. The early reforms separated central banking (People's Bank of China) from commercial banking (four specialized banks). Since 1986 reforms have diversified the structure of the financial sector (including non-bank financial institutions), allowed a broader array of financial instruments, and increased bank autonomy in pricing and use of funds.

20. Beginning in 1984 , total lending depended on deposits and a fixed amount of credit funds provided by the People's Bank.

21. The government was claiming residual control rights for situations not specified in the implicit contract. Analogous arrangements include the authority of German banks to manage firms when the firm is failing or being mismanaged or the practice of village leaders in China to adjust household land allocations if 'it is determined that it is not being used to the best of its potential for the good of the state' (Rozelle, 1994).

22. Most policy-makers blamed grain price inflation on market liberalization measures in 1993 which led to reduced sown area to grain as quotas and other administrative measures were abolished. Others have pointed to rising demand accompanying large wage increases and rising rural incomes, or the desire of farmers to hedge against inflation by stockpiling grain.

23. Some argue that retrenchments were also motivated by the desire to protect local fertilizer factories from competition and maintain the government's political leverage from distributing rationed fertilizer. Reforms in the 1990 s resembled efforts to recentralize fertilizer trade by giving a monopoly over distribution to SMCs and AICs in the late 1980s. Government circulars were passed down in October 1987, autumn 1988, and January 1989 (Stone, 1989).

24. The national government was to set prices for imports and for fertilizer produced by the nation's 13 large-scale fertilizer plants, provincial price bureaux were to set the price for medium-scale factories, and prefectural price bureaux were to set the price for small-scale factories. The provincial government was then to set a uniform retail price, taking all of these prices into consideration.

25. Three types of agricultural research and extension stations were allowed to engage in fertilizer trade (nongye san zhan): plant protection stations (zhiboa zhan), soil science stations (tufei zhan), and agricultural technology extension stations (nongji tuiguan zhan). Medium-scale factories could sell up to 10 per cent of production and small-scale factories 20 per cent.

26. Seen in a visit to a Shanghai retail grain outlet in 1994 .

27. Barzel (1989), for instance, describes in detail similar responses by gas station managers to gasoline price ceilings imposed in the US in the 1970s.

28. Interview with researcher from the Research Center for Rural Economy, Ministry of 
Agriculture, April 1996.

29. In Hebei Province, the number of market participants in fertilizer trade reached as much as 70,000 (Zhang, 1994). Recent investigations found that the market share of AIC outlets ranged from 20 to 30 per cent in regions of Sichuan and Hebei (NPCMPIT, 1995).

30. This figure is from Fulton and Xiao (1997).

31. Lyons reports examples from Fujian in the late 1980s. One report found that only 38 per cent of planned fertilizer allocations reach farmers. In one county 7.1 out of 51 tons of planned fertilizer went to favoured individuals. In one county, four SMC depots illegally sent shipments of fertilizer to Zhejiang for a higher profit.

32. These loans achieve the lowest repayment rate compared to other loan categories. They primarily go to poor rural households or to rural enterprises that employ the poor. The county Poor Area Development Office (PADO), usually with close ties to the county government, is responsible for poverty loan allocation, but the loans are administered by the $\mathrm{ABC}$ (later the $\mathrm{ADB}$ ), which receives government subsidies to cover the interest subsidies. At the county level, there are frequently disputes over what projects should receive targeted poverty loans ( $\mathrm{Li}$ and $\mathrm{Li}, 1993$; Wu G., 1995), the PADO emphasizing poverty alleviation objectives while the $\mathrm{ABC}$ stresses repayment ability. In one county, poverty funds were withdrawn from the county because the county $A B C$ refused to approve any of the projects proposed by the PADO. Banks can also use other methods to minimize profit losses and undermine policy: divert loans outright, delay loan disbursement, or demand earlier repayment so the money can be re-lent at a higher interest rate.

33. This was especially true after the initial establishment of the ADB when ADB branches were established only at the provincial level but not the county level. The $\mathrm{ADBs}$ enlisted county $\mathrm{ABCs}$ to implement policy loans on their behalf, creating moral hazard problems even worse than before because the loans were no longer on the balance sheets of the $A B C$, increasing the incentive to divert loans and neglect monitoring. The government, to its credit, became aware of this unintended consequence of institutional reform and in 1997 established sub-provincial ADBs.

34. Also see Sicular (1995) and Cheng (1996).

35. This was especially true for regions along the Yangtze river where small barges were extremely difficult to monitor.

36. An exception was made for sales in remote regions that could not support regular outlets.

37. Authors' interviews with a provincial official in Sichuan, December 1995, and with a county grain bureau director in Guizhou Province, May 1996.

38. Problems still remain in fully disengaging the $A B C$ from policy lending and in keeping the Agricultural Development Bank from engaging in commercial trade. For example, the $\mathrm{ABC}$ is the main lender to the SMCs, providing significant capital even though many SMCs are losing money and are questionable credit risks.

39. Supplementary base compensation for Development Bank staff was intended to equalize the incentives for working at each of the banks. Because base salary levels were highly regulated, extra base compensation could take the form of extra nonsalary goods or services made available to employees, which would be expensed as operating costs. 


\section{References}

Aghion, P. and J. Tirole (1997), 'Formal and Real Authority in Organizations', Journal of Political Economy, 105(1), pp.1-29.

Barzel, Y. (1989), Economic Analysis of Property Rights, Cambridge: Cambridge University Press.

Berkowitz, J., D. N. DeJong and S. Husted (1996), 'Market Reform in Russia: It's Happening', unpublished paper, University of Pittsburgh.

Brandt, L. and X. Zhu (1997), 'Redistribution in a Decentralizing Economy: Growth and Inflation in Reform China', unpublished paper, University of Toronto.

Central Committee of the Communist Party and the State Planning Commission (CCPCPSPC, or zhonggong zhongyang guowuyuan) (1995), 'Decisions Concerning the Deepening of Reform of Agricultural Inputs Co-operative (guanyu shenhua gongshao hezuoshe gaige de jueding),' China Business Report (zhongguo shangbao), No.3.

Cheng, E. (1996), 'Rural Financial Markets', In: Watson, A., (ed.), Markets in China: the Role of Markets in a Partially Reformed Economy, Oxford: Oxford University Press.

Cheng, E. (1997), 'Market Reforms and Provision of Credit for Grain Purchases in China', The China Quarterly, 151, pp.633-53.

China Daily (1998), 'Grain Marketing System to be Restructured', p.1.

Ding, S. (1995), 'To Foster and Perfect China's Rural Market System', paper presented at the Conference on Market Economy and China's Agriculture: Problems and Prospects, Fudan University, Shanghai, December 7-8.

Eggertsson, T. (1990), Economic Behaviour and Institutions, Cambridge: Cambrige University Press.

Fulton, M. and Y. Xiao (1997), 'Fertilizer Market Development in China', paper presented at the annual meetings of the Association of Asian Studies, Chicago, March.

Holmstrom, B. and P. Milgrom (1991), 'Multitask Principal-Agent Analyses: Incentive Contracts, Asset Ownership, and Job Design', Journal of Law, Economics, and Organization, 7, pp.24-52.

Laffont, J.-J. and J. Tirole (1991), 'Privatization and Incentives', Journal of Law, Economics, and Organization, 7, pp.84-105.

Lyons, T. (1992), 'Market-Oriented Reform in China: Cautionary Tales', unpublished paper, Cornell University.

Milgrom, P. and J. Roberts (1992), Economics, Organization, and Management, Englewood Cliffs, N.J.: Prentice-Hall.

National Planning Commission Market Price Investigation Team (NPCMPIT, or zhongjia jiwei shichang wujiasi diaocha zu) (1995), 'Investigation of Institutional Reform of Cotton, Fertilizer, and Oil Product Distribution (dui mianhua, huafei, chengpinyou liutong tizhi gaige qingquang de diaocha)', Macro-Economic Management (hongguan jingji guanli), March, pp.31-4.

Naughton, B. (1995), Growing Out of the Plan, New York: Cambridge University Press.

North, D. (1990), Institutions, Institutional Change, and Economic Performance, Cambridge: Cambridge University Press.

Park, A., S. Rozelle, C. Wong and C. Ren (1996), 'Distributional Consequences of Reforming Local Public Finance in China', The China Quarterly, 147, pp.751-78.

Putterman, L. (1992), 'Dualism and Reform in China', Economic Development and Cultural Change, 40(3), pp.467-93. 
Rozelle, S. (1994), 'Decision-Making in China's Rural Economy: The Linkages between Village Leaders and Farm Households', The China Quarterly, 137, pp.99-124.

Rozelle, S. (1996), 'Gradual Reform and Institutional Development: the Keys to Success of China's Rural Reforms', In: McMillan, J. and B. Naughton, (eds.), Reforming Asian Socialism: The Growth of Market Institutions, Ann Arbor: University of Michigan Press.

Rozelle, S., A. Park, J. Huang and H. Jin (1998), 'Market Emergence and Transition: Transaction Costs, Arbitrage, and Autarky in China's Grain Markets', unpublished paper, University of California at Davis.

Rozelle, S., A. Park, J. Huang and H. Jin (forthcoming), 'Bureaucrat to Entrepreneur: The Changing Role of the State in China's Grain Economy', Economic Development and Cultural Change, forthcoming.

Sicular, T. (1988), 'Agricultural Planning and Pricing in the Post-Mao Period', The China Quarterly, 116, pp.671-703.

Sicular, T. (1995), 'Redefining State, Plan, and Market: China's Reforms in Agricultural Commerce', The China Quarterly, 144, pp.1,020-46.

State Statistical Bureau (1989), China Supply and Marketing Co-operative Statistics (zhongguo gongxiao hezuoshe tongji ziliao) 1949-1988, Beijing: Statistical Press.

State Statistical Bureau (1994),. China Rural Financial Statistics (zhongguo nongcun jinrong tongji) 1993, Beijing: Statistical Press.

State Statistical Bureau (1995), China Statistical Yearbook (zhongguo tongji nianjian) 1995, Beijing: Statistical Press.

Stone, B. (1989), 'Fertilizer's Greener Pastures', The China Business Review, Sept-Oct.

Tam, On Kit, (ed.) (1995), Financial Reform in China, London and New York: Routledge.

Wong, C., C. Heady and W. Woo (1995), Fiscal Management and Economic Reform in the People's Republic of China, Hong Kong: Oxford University Press.

The World Bank (1990), China: Financial Sector Policies and Institutional Development, Washington, D.C.: The World Bank.

Wu, X. (1994), 'Agricultural Input Prices: Problems, Causes, and Policies (nongye shengchan ziliao jiage: wenti, yuanyin yu duice)', Price Theory and Practice (jiage lilun yu shijian), 12, pp.14-18.

Xia, B. (1995), 'China's Interbank Money Market', In: Tam, O. K., (ed.), Financial Reform in China, London and New York: Routledge.

Xu, X., Y. Deng, X. Yuwei, L. Jianjin and H. Bin (1994), China Rural Financial Reforms and Development (zhongguo nongcun jinrong de gaige yu fazhan), Beijing: Modern China Press.

Ye, Q. (1991), 'China's Small-Scale Nitrogen Fertilizer Sector: A Trip Report', unpublished paper, Stanford University.

Zhang, G. (1994), 'Agricultural Input Prices Should be Liberalized (nongye shengchan ziliao jiage yingdang kaifang)', Price Theory and Practice (jiage lilun yu shijian), 9, pp.31-35. 